\title{
Seasonal changes in the composition of the diets of Peary caribou and muskoxen on Banks Island
}

\author{
Nicholas C. Larter \& John A. Nagy
}

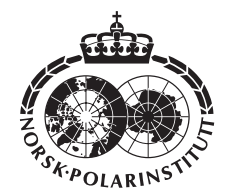

Caribou and muskoxen are the only ungulate species occupying Arctic tundra environments. We analysed plant fragments found in fresh $(<4 \mathrm{hr}$ old) samples of faecal material to determine the diets of Peary caribou (Rangifer tarandus pearyi) and muskoxen (Ovibos moschatus) on Banks Island, Canada. Willow was a major component of the diets of both animals, dominating the caribou diet during summer and representing substantial proportions of the muskoxen diet during at least seven months of the year. The diet of caribou was more diverse than that of muskoxen and was dominated by sedge, willow (Salix arctica), legume (Astragalus spp., Oxytropis spp.) and Dryas integrifolia. The diet of muskoxen was dominated by sedge and willow. There was substantial overlap (up to $70 \%$ ) in the diets of these herbivores with the similarity more pronounced in areas of high muskox density ( $c a .1 .65$ animals $/ \mathrm{km}^{2}$ ). We discuss herbivore diets in relation to foraging behaviour and forage availability.

N. C. Larter, Government of the Northwest Territories, Department of Resources, Wildife \& Economic Development, Box 240, Ft. Simpson, NT, Canada XOE 0N0, nic_larter@gov.nt.ca; J. A. Nagy, Government of the Northwest Territories, Department of Resources, Wildlife \& Economic Development, Bag Service \#l, Inuvik, NT, Canada XOE OTO.

Caribou (Rangifer tarandus) and muskoxen (Ovibos moschatus) are the only ungulate species successfully occupying Arctic tundra environments. Caribou and muskoxen have different morphological adaptations which presumably enabled them to utilize forage resources with little overlap (Klein 1992). Caribou, with their small body size, narrow muzzle, small gut capacity, and rapid passage rate (Tyler \& Blix 1990; Klein 1992), are representative of a mixed feeder type, intermediate between roughage feeders and concentrate selectors according to Hofmann's (1989, 2000) classification. Muskoxen, with their large body size, broad muzzle, and large gut capacity capable of processing large amounts of low quality forage (Klein 1992) are representative of roughage feeders (grazers) according to Hofmann's $(1989,2000)$ classification.

A number of studies have reported the diets of muskoxen and caribou in Arctic Canada (e.g. Wilkinson et al. 1976; Parker 1978; Shank et al.
1978; Thomas \& Edmonds 1983; Oakes et al. 1992; Larter \& Nagy 1997), Alaska (e.g. Svendsen 1992; Ihl 1999; Ihl \& Klein 2001), and Greenland (Thing 1984; Thing et al. 1987; Klein \& Bay 1990). Many diet studies have shown willow (Salix spp.) to be a noticeable component of the muskoxen diet regardless of season (e.g. Wilkinson et al. 1976; Thing 1984; Svendsen 1992; Larter \& Nagy 1997; Thomas et al. 1999). In early summer, willow use was prominent among muskoxen on Banks Island (Larter \& Nagy 1997). Willow is also a prominent component of their late winter diet especially in years of deeper and harder snow (Larter \& Nagy 1997; Thomas et al. 1999).

Lichen is an important winter food for barrenground caribou on the mainland, but in the High Arctic islands, which support low lichen biomass, caribou must use other forages, usually willow and graminoids (Reimers et al. 1980; Klein 1992). Where food choices are limited or muskox density is high, the two species may compete for food 
(McKendrick 1981). On Banks Island in the Canadian High Arctic, lichen biomass is low and the muskox population represents a substantial proportion of worldwide muskoxen numbers, with some of the highest reported densities of muskox, 1.5-2.0 animals $/ \mathrm{km}^{2}$ (Nagy et al. 1996; Larter \& Nagy 2001a). During the 1990s Peary caribou numbers on Banks Island were at historic lows, 500 - 1000 animals, excluding calves (Nagy et al. 1996). Peary caribou rely on willow during the short Arctic summers in order to regain fat prior to winter and there was concern that the availability of willow during summer may be impacted by the increased annual use of willows by herbivores (Larter \& Nagy 1997; Larter 1999).

In order to describe, in detail, the seasonal diet composition of Peary caribou and muskoxen on Banks Island we embarked on a program to collect fresh faecal samples deposited on known dates during every month of the year. We hypothesized that muskoxen would feed on willow to a greater extent during the growing season when willow was of higher nutritive quality (Larter \& Nagy 2001b) and/or during late-winter when the availability of sedge (Carex spp., Eriophorum spp.) would be lowest, due to the combination of grazing and snow conditions (Larter \& Nagy 2000, 2001c). We also hypothesized that the diet composition of muskox would be different in areas of different muskox density. This paper documents the monthly diets Peary caribou, the monthly diets of muskoxen residing in areas of both high and low muskox density, the percent similarity in diet between the two animals, and relates the monthly changes in diet to foraging behaviour.

\section{Study area}

Banks Island is the westernmost island in the Canadian Arctic archipelago and covers approximately $70000 \mathrm{~km}^{2}$ (Fig. 1). The climate is Arctic maritime along coastal areas where weather stations are located, tending toward Arctic desert inland (Zoltai et al. 1980). Winters are long and cold; mean monthly temperatures are below $0^{\circ} \mathrm{C}$ from September through May; mean minimum daily temperatures range from $-30^{\circ} \mathrm{C}$ to $-40^{\circ} \mathrm{C}$ from December to March. Summers are short and cool; mean maximum daily temperatures range from $5^{\circ} \mathrm{C}$ to $10^{\circ} \mathrm{C}$ from June through August. There is little precipitation; the annual mean is
$90 \mathrm{~mm}$ (Zoltai et al. 1980). Sachs Harbour (population 125 ) is the only permanent settlement on the Island.

Habitat descriptions were adapted from Kevan (1974), Wilkinson et al. (1976), and Ferguson (1991). There are four major terrestrial habitats: 1) wet sedge meadow, 2) upland barren, 3) hummock tundra, and 4) stony barren. Muskoxen and caribou forage in all habitats. Wet sedge meadows (WSM) are generally level hydric and hygric lowlands characterized by Carex aquatilis, Eriophorum scheuchzeri, and Dupontia fisheri. Upland barrens (UB) are well drained sites found on the upper and middle parts of slopes. Vegetation is dominated by Dryas integrifolia and Salix arctica. Hummock tundra (HT) is found on moderately steep slopes and is characterized by individual hummocks which are vegetated primarily by dwarf shrubs (D. integrifolia, S. arctica, with some Cassiope tetragona). Stony barrens (SB) have a coarse gravelly substrate and are found in windblown areas, on ridges and on gravel and sand bars; vegetation is sparse.

The areas of high and low muskox density where samples were collected for this study cover 2700 and $18400 \mathrm{~km}^{2}$, respectively, and have had distinctly different densities of muskox since 1985 (Nagy et al. 1996). Similar vegetation types and vegetation of similar quality are found throughout both areas (Larter \& Nagy 2001b). However, in the low density area, vegetated habitats are more patchily distributed with SB being more prominent (Larter \& Nagy unpubl. data) and latewinter snow conditions tend to be harsher (Larter \& Nagy 2001c).

A more detailed description of the flora of Banks Island can be found in Wilkinson et al. (1976), Porsild \& Cody (1980), and Zoltai et al. (1980). Plant taxonomy follows Kartesz (1999).

\section{Methods}

Two field camps were established in June 1993 on south central Banks Island (Fig. 1): one camp (Coyote) is located in an area of high muskox density (1.6 - 1.9 muskox $/ \mathrm{km}^{2}$ ) about $90 \mathrm{~km} \mathrm{ESE}$ of Sachs Harbour, and the other (Bernard) in an area of low muskox density (0.3-0.4 muskox/ $\mathrm{km}^{2}$ ) about $130 \mathrm{~km} \mathrm{ENE}$ of Sachs Harbour (Fig. 1). From June 1993 to May 1998 we made six trips to these camps annually in June, July, August, November-December, February, and April - May. 


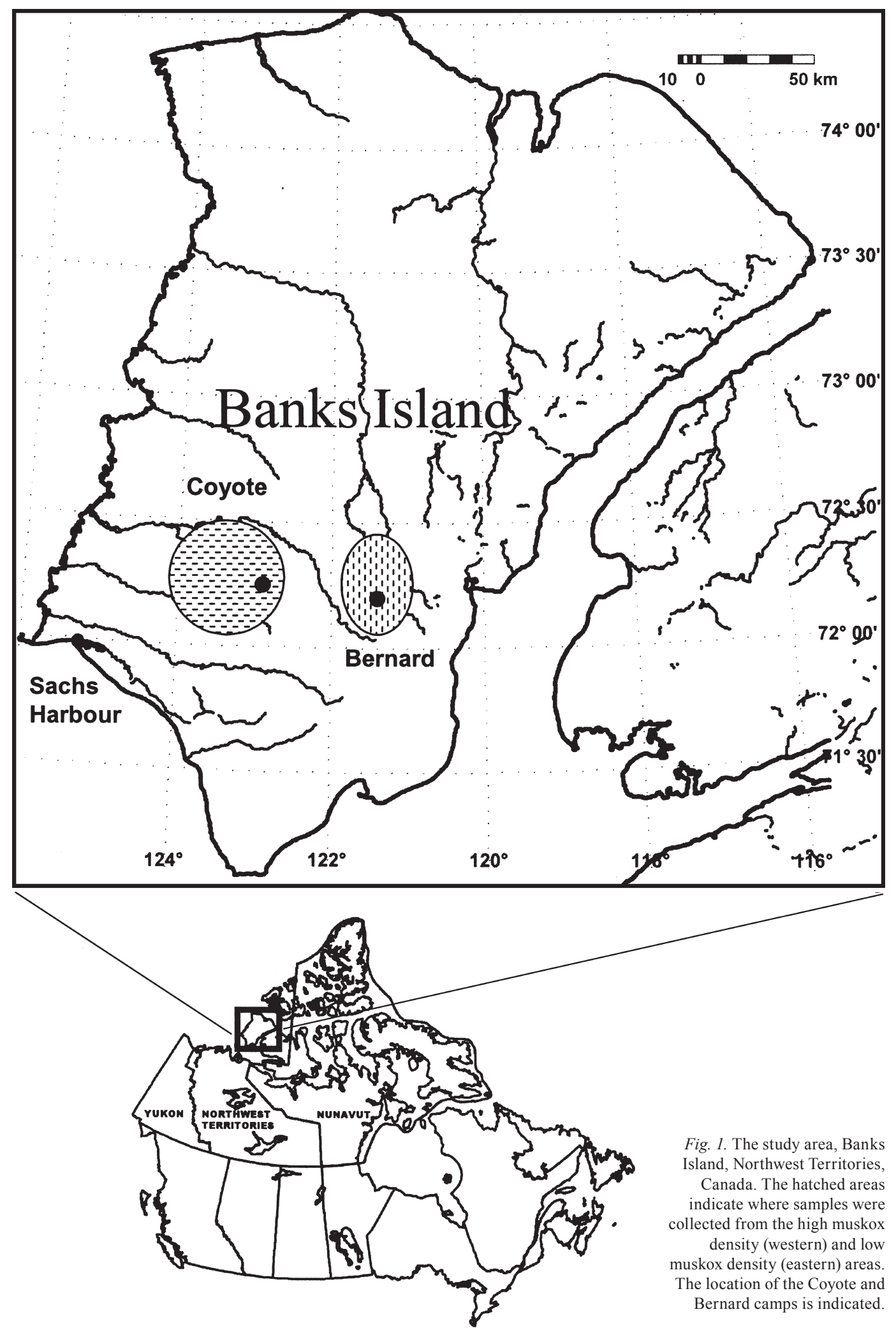


We collected fresh $(<4$ hr old) Peary caribou faecal samples opportunistically during all these field trips. Additional faecal samples were collected during field trips in March and May 1993 and January 2001, from animals killed by hunters (since 1990), and from animals taken during a collection in winter 1993-94. In total 298 samples were analysed from all months, range of 10 to 49 samples/month. We present monthly diet composition pooled across sex and age classes and years with the individual caribou as the sample unit. We assume inter-annual variation was minimal.

Previous analyses (Larter \& Nagy 1997) indicated that between-group variation was greater than within-group variation in the diet of muskox. Therefore, we assumed that a composite sample of fresh $(<4$ hr old $)$ muskox faeces from a number of individuals in a group was representative of that group of muskox and that by sampling groups instead of individuals we would get a better measure of the diet over a larger portion of the muskox population. Thus, we used the composite sample from a muskox group as the sample unit. Initially (March 1993) the sample unit consisted of five pellet groups; this was reduced to three pellet groups/muskox group. Small pellets (i.e. from calves) were not included in composite samples. We collected faecal samples from mixed sex and age groups during field trips conducted between March 1993 and May 1998 and during September, October, and December 2000 and January 2001. This provided data for all months of the year from the high density area, and for all months except January, September and December in the low density area. We recorded the number of individuals present in each group we collected faecal samples from. The number of groups sampled per month during the sampling period ranged from 2 to 29 , representing between 63 and 634 animals in the high density muskox area, and from 1 to 23 , representing between 30 and 371 animals, in the low density muskox area. We present mean monthly diet composition of muskoxen pooled across years with the group as the sample unit, weighted by the number of individuals in a group. January and September data from the high density area and May and October data from the low density area are from one year only. We assume inter-annual variation was minimal.

Faecal samples were thawed, air dried for $24 \mathrm{hr}$, oven dried at $60^{\circ} \mathrm{C}$ for $48 \mathrm{hr}$, and ground through a $1 \mathrm{~mm}$ screen with a centrifugal mill. Subsamples (ca. $1 \mathrm{~g}$ dry weight) were forwarded to the Com- position Analysis Laboratory, Ft. Collins, Colorado, for analysis. Diet composition was determined by analysing plant fragments (Sparkes \& Malechek 1968) according to Hansen et al. (1976). The microhistological technique has inherent limits, such as an inability to separate some species, and a limited percent of identifiable fragments in the slides (Johnson et al. 1983; Barker 1986). However, we deemed this method suitable for this study, since we were interested in the proportional dietary contribution of different forage classes, not of individual species. Moreover, this method had been used in previous work on Banks Island (Oakes et al. 1992; Larter \& Nagy 1997). The diet was subdivided into the following forage classes: sedge (Cyperaceae), willow (predominantly Salix arctica), grass (Poaceae), rose/saxifrage (Rosaceae and Saxifragaceae but predominantly Dryas integrifolia), legume (Oxytropis spp., Astragalus spp.), fruticose lichen (Cetraria spp., Cladonia spp., Cladina spp., Peltigera spp., and Thamnolia subuliformis), and other (other forbs, moss, and Equisetum spp.). No samples had completely unidentifiable material. There were traces $(\leq 1.93 \%)$ of unidentifiable grass, and forb material. These were included in their respective categories. Trace $(\leq 0.1 \%)$ quantities of rush were included as grass.

We used Simpson's Index (SI) (Krebs 1989) as a measure of monthly diet diversity. Annual diet diversity was calculated as the mean of monthly SI over twelve months for caribou and muskoxen in high density areas, and over eight months for muskoxen in low density areas. We used the Renkonen index (Renkonen 1938; Krebs 1989) to compare monthly percent diet similarity (PS) between Peary caribou and muskoxen in high and low muskox density areas. This index determines PS by summing the lower percentage of each individual forage class in the diets being compared. We compared monthly diet similarity between Peary caribou and muskox both within and between months. We used the same forage classes as above except that the sedge class was subdivided into Carex spp. and Eriophorum spp. and that the moss component was reported separately from the other category. We considered PS $>50 \%$ as substantial diet similarity. We used the sign test (Conover 1980) to compare the amounts of willow and sedge in the diet of muskoxen in low and high density areas. 


\section{Results}

The annual diet of caribou, Simpson's Index (SI) of 0.704, was more diverse than that of muskoxen in both high (SI 0.433) and low (SI 0.314) density areas, and was dominated by four forage classes: sedge, willow, legume, and rose/saxifrage (predominantly Dryas integrifolia) which varied in their monthly contribution to the die (Fig. 2a). Willow was the dominant dietary component during summer (June-August). Legumes and Dryas integrifolia represented $\geq 50 \%$ of the diet from October to May. The sedge component of the diet was generally between 15 and $25 \%$ for all months except January, April, May and July. Lichen and grass use was negligible $(\leq 5 \%)$ except during January. Diet diversity was greatest in January and September (SI 0.811 and 0.809, respectively), when the four dominant forage classes made up $<75 \%$ of the diet: $74 \%$ in January and $66 \%$ in September (Fig. 2a).

The annual diet of muskoxen in both high and
Fig. 2. Monthly diet composition, mean percent relative density of faecal plant fragments, of a) Peary caribou, b) muskoxen in high density areas, and c) muskoxen in low density areas. Values over each histobar are the number of samples. For caribou, samples represent individuals. For muskoxen, samples represent groups. An asterisk indicates data from one year only.
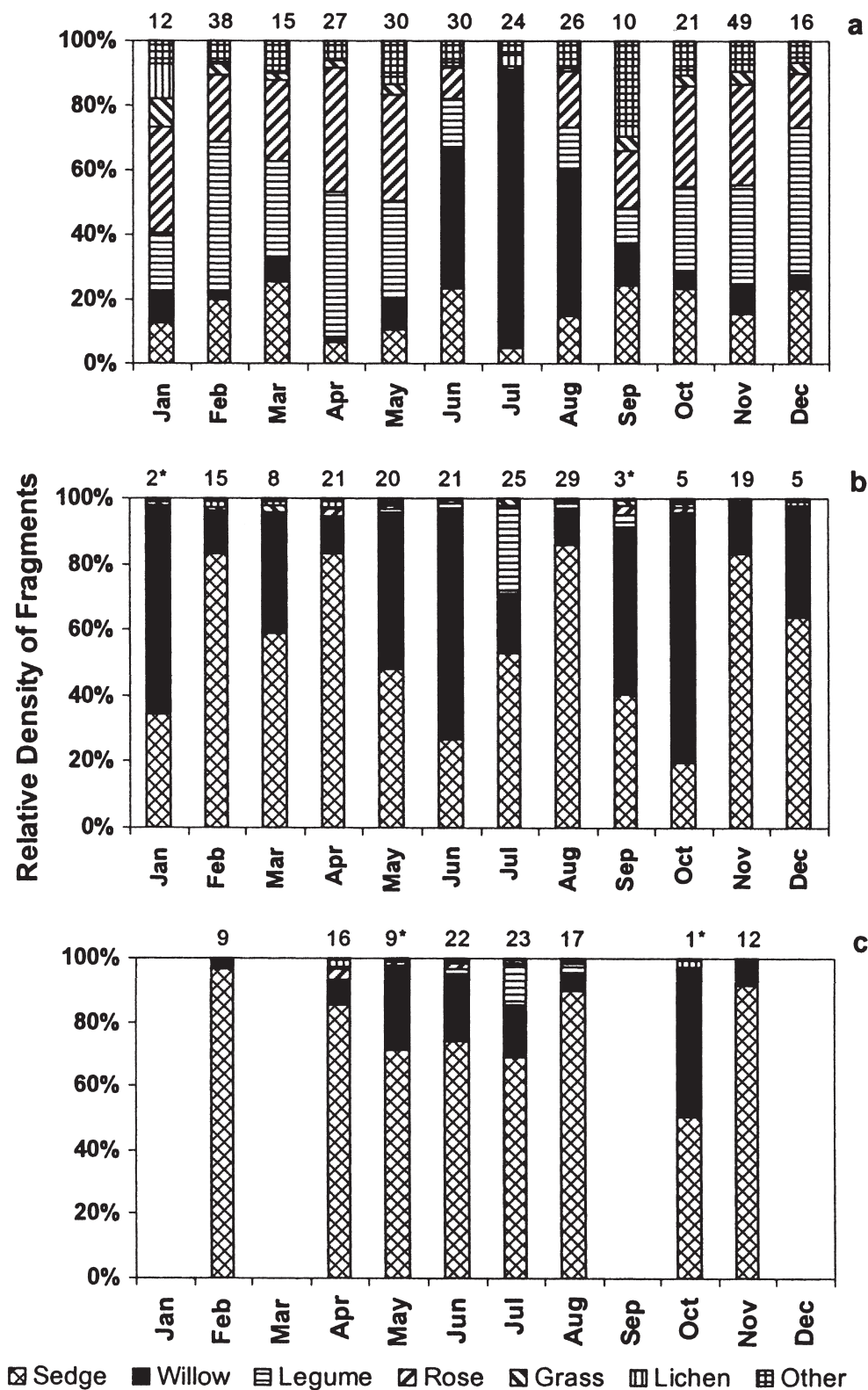
low density areas was dominated by two forage classes, sedge and willow (Fig. 2b, c). Sedge and willow made up $c a$. $95 \%$, or more, of the diet in all months except July, when legume use was noticeable. Muskoxen in high density areas tended to have somewhat more willow and less sedge $(\mathrm{P}<0.01 ; 1$-tailed $)$ in their monthly diets when compared to muskox in low density muskox areas (Fig. 2b, c). In high density areas, substantial willow use (48-75\%) occurred during five months of the year: January, May, June, September and October. In low density areas, willow use was highest during October (46\%), May (25\%), and June $(20 \%)$; there were no data for January and September.

Only in June was there substantial overlap $(71 \%)$ in diet between Peary caribou and muskox in high density areas. However, there was substantial overlap between the summer (June-August) diet of caribou and the fall diet (September and October) of muskox and between the July diet of muskox and the February, March and June diet of caribou (Table 1). The April diet of Peary caribou, with its low sedge and willow content, was the least similar to the diet of muskoxen. Similar patterns of diets were found for Peary caribou and muskox in low density areas (Table 2). For any month, the diets of muskoxen in high and in low density areas had substantial similarity (Table 3 ). In the three months with lowest similarity (May $57 \%$, June $51 \%$ and October $67 \%$ ) the greater use of willow by muskoxen in high density areas relative to those in low density areas caused the reduction in diet similarity (Table 3; Fig. 2b, c).

\section{Discussion}

At the start of the growing season the levels of anti-herbivore defence compounds in deciduous species are low (Chapin et al. 1980) and willow leaves are of their highest quality (Murray 1991; Larter \& Nagy 2001b). Muskoxen grazed almost exclusively on willow leaves during the start of the growing season at Sverdrup Pass, Ellesmere Island (Murray 1991; Raillard 1992). Similarly, we found high use of willow by muskoxen during May and June, consistent with the hypothesis that foraging on willow occurs during the early growth stages when leaves and young shoots are emerging and plants are of high nutritive quality. We did not expect muskoxen would feed on willow to such an extent during the fall (September and October) and in January (Fig. 2b, c). The fibre and lignin content of willow leaves and stems increases over the course of the growing season with a corresponding decrease in digestibility (Hartley \& Jones 1997; Larter \& Nagy 2001b). By fall and winter, willow leaves and stems have lignified and are certainly not of the high nutritive quality they were at the start of the growing season. Sample sizes for these months were smaller than for other months and may not have provided an accurate reflection of the diet; however, the percent willow in any individual sample was $\geq 37 \%$ which implies willow was an important dietary component for muskoxen during September, October and January.

The diet of Cape Bathurst caribou (Rangifer tarandus groenlandicus), found on the main-

Table 1. The Renkonen index of percent similarity between the monthly diets of muskox and caribou in high muskox density areas. Substantial overlap $(>50 \%)$ indicated by bold print.

\begin{tabular}{|c|c|c|c|c|c|c|c|c|c|c|c|c|}
\hline & Jan. & Feb. & Mar. & Apr. & May & Jun. & Jul. & Aug. & Sep. & Oct. & Nov. & Dec. \\
\hline January & 20.8 & 27.4 & 27.9 & 28.7 & 27.5 & 26.9 & 43.4 & 26.7 & 27.4 & 23.7 & 21.9 & 26.5 \\
\hline February & & 25.6 & 26.7 & 27.2 & 26.8 & 21.7 & 51.3 & 26.0 & 28.1 & 24.0 & 22.6 & 25.2 \\
\hline March & & & 38.1 & 38.9 & 37.6 & 33.0 & 62.2 & 36.8 & 33.2 & 29.5 & 27.6 & 34.9 \\
\hline April & & & & 13.6 & 12.9 & 12.4 & 37.4 & 12.1 & 16.9 & 13.0 & 10.5 & 11.6 \\
\hline May & & & & & 24.8 & 24.2 & 49.3 & 24.0 & 28.6 & 24.9 & 22.3 & 23.9 \\
\hline June & & & & & & 70.8 & 53.1 & 37.7 & 60.6 & 57.2 & 27.7 & 52.4 \\
\hline July & & & & & & & 24.9 & 18.0 & 58.9 & 84.2 & 21.9 & 41.0 \\
\hline August & & & & & & & & 29.5 & 67.5 & 63.7 & 32.1 & 50.7 \\
\hline September & & & & & & & & & 36.0 & 32.2 & 30.4 & 37.5 \\
\hline October & & & & & & & & & & 27.1 & 25.3 & 28.7 \\
\hline November & & & & & & & & & & & 25.8 & 32.1 \\
\hline December & & & & & & & & & & & & 31.1 \\
\hline
\end{tabular}


land of the Northwest Territories to the south of Banks Island, was $>85 \%$ willow during late June and July (N. Larter \& J. Nagy unpubl. data), and we expected Peary caribou, being a mixed feeder, also to forage on high quality patchily distributed forage such as willow during the growing season. During July the Peary caribou diet was least diverse (SI 0.276) and willow made up $85 \%$ of the diet. In June and August, willow constituted $c a .45 \%$ of the diet of Peary caribou on Banks Island (Fig. 2a). Willow use peaked in July when the available biomass of willow leaf crude protein was at its greatest (Larter \& Nagy 2001b; N. Larter \& J. Nagy unpubl. data). This pattern of foraging is consistent with the multiplier effect in ruminant physiology (White 1983), where selective foraging on high quality foods has a positive influence on animal production, and it occurred during a period of milk production (for females) and fat deposition. Body size and fat reserves have a powerful effect on calf production and age of first reproduction of reindeer and caribou (Dauphine 1976; Leader-Williams 1980; Thomas 1982).

Some studies indicated that legumes were an important component of the summer diet of muskoxen on Banks Island and that their forag- ing behaviour may shape regrowth and reproduction of Oxytropis borealis (Oakes et al. 1992; Mulder \& Harmsen 1995). We found a fair amount of legume in the July diet of muskoxen, but negligible use during the other months of the year. Legumes were at their highest digestibility in July (Larter \& Nagy 2001b). Selective feeding on highly digestible legumes in July may represent a multiplier effect (White 1983) for Banks Island muskoxen. The proportion of legume in the July diet was higher for muskoxen in high density areas (Fig. 2b, c). Legumes made up substantial portions of the monthly diet of caribou from October through May; July was the only month caribou did not feed on legumes (Fig. 2a). Legumes are an ideal forage for mixed feeders like caribou during winter. They are patchily distributed throughout upland habitats (Larter \& Nagy 2001d) and have a substantially higher crude protein content ( $\mathrm{ca}$. $12 \%$ ) than other available forages (Larter \& Nagy 2001b).

Larter \& Nagy (1997) indicated that the differences in the diet of muskoxen between areas of high and low density may have been related to forage availability. Greater use of legumes by muskoxen in high density areas may be a result of

Table 2. The Renkonen index of percent similarity between the monthly diets of muskox and caribou in low muskox density areas. Substantial overlap $(>50 \%)$ indicated by bold print.

\begin{tabular}{lrrrrrrrr}
\hline & Feb & Apr & May & Jun & Jul & Aug & Oct & Nov \\
\hline February & 21.6 & 27.4 & 25.4 & 28.2 & 36.9 & 27.0 & 22.7 & 23.7 \\
April & & 13.8 & 11.9 & 14.3 & 23.1 & 13.2 & 11.5 & 9.9 \\
May & & & 23.8 & 26.2 & 35.0 & 20.9 & 23.2 & 19.2 \\
June & & & & 49.6 & $\mathbf{5 4 . 2}$ & 33.5 & $\mathbf{5 6 . 2}$ & 22.1 \\
July & & & & & 24.2 & 12.7 & $\mathbf{5 3 . 7}$ & 13.2 \\
August & & & & & & 25.3 & $\mathbf{6 2 . 6}$ & 23.5 \\
October & & & & & & & 25.4 & 27.9 \\
November & & & & & & & & 24.2 \\
\hline
\end{tabular}

Table 3. The Renkonen index of percent similarity between the monthly diets of muskox in high and low muskox density areas. Substantial overlap $(>50 \%)$ indicated by bold print.

\begin{tabular}{lrrrrrrrr}
\hline & Feb & Apr & May & Jun & Jul & Aug & Oct & Nov \\
\hline February & $\mathbf{7 9 . 5}$ & $\mathbf{8 7 . 3}$ & 37.9 & $\mathbf{6 6 . 5}$ & $\mathbf{7 7 . 4}$ & $\mathbf{8 6 . 0}$ & $\mathbf{6 4 . 5}$ & $\mathbf{8 7 . 8}$ \\
April & & $\mathbf{9 4 . 0}$ & 43.0 & $\mathbf{7 2 . 2}$ & $\mathbf{8 1 . 5}$ & $\mathbf{9 0 . 3}$ & $\mathbf{6 3 . 1}$ & $\mathbf{8 2 . 7}$ \\
May & & & $\mathbf{5 6 . 9}$ & $\mathbf{7 1 . 9}$ & $\mathbf{6 7 . 3}$ & $\mathbf{5 5 . 8}$ & $\mathbf{8 2 . 7}$ & 47.8 \\
June & & & & $\mathbf{5 0 . 7}$ & 46.4 & 35.2 & $\mathbf{5 8 . 8}$ & 24.9 \\
July & & & & & $\mathbf{8 3 . 4}$ & $\mathbf{6 3 . 0}$ & $\mathbf{6 1 . 4}$ & $\mathbf{5 5 . 6}$ \\
August & & & & & & $\mathbf{8 8 . 3}$ & $\mathbf{6 1 . 6}$ & $\mathbf{7 2 . 7}$ \\
October & & & & & & & $\mathbf{6 6 . 6}$ & 28.1 \\
November & & & & & & & & $\mathbf{9 1 . 3}$
\end{tabular}


availability. The frequency of occurrence (Larter \& Nagy 2001d) and aboveground standing crop (N. Larter \& J. Nagy unpubl. data) of legumes was greater in habitats in the high muskox density area. This was not the case for willows or sedges in wet sedge meadows, which had similar availability in areas of high and low muskox density; yet the willow proportion of the diet in summer is greater for muskoxen in high density areas. Larter \& Nagy (2001a) indicated that a per capita decrease in summer sedge availability at peak muskox densities was the likely cause of the larger willow component of the summer diet. Greater intraspecific competition for sedge would explain why sedge remained a lower proportion of the summer diet of muskoxen in high density areas (Fig. 2b).

During winter, muskoxen in the High Arctic generally forage in moister habitats where there is an abundance of monocots, generally sedge (Urquhart 1973; Schaefer \& Messier 1995a, 1995b; Thomas et al. 1999; Larter and Nagy 2001c). This would be expected of a grazing animal. If muskox select wet sedge meadow habitat throughout winter, why do muskoxen in high density areas have so much willow in the diet during some months? Sedges do constitute the majority of forage biomass in wet sedge meadows on Banks Island; however, willow is often found in this habitat (Larter \& Nagy 2001d). We believe that the decrease in the sedge component and the increase in the willow component of the diet from November to January is caused by changing forage availability in wet meadows as a result of foraging by muskoxen, and the onset of 24-hr darkness. Muskox move into wet meadows once the ground is frozen in November and actively forage on sedges, thus decreasing sedge biomass relative to willow biomass and making the snow cover harder as a result of cratering for forage. During the period of 24-hr darkness and after the onset of extreme cold (December through mid-January) there appears to be a reluctancy to search for ungrazed meadows. In February, with the rapid return of daylight, we believe that the animals search for ungrazed meadows to meet foraging requirements and again remain in these localized areas through March, as indicated by a decrease in the sedge and an increase in the willow component of the diet. By mid-April the extreme cold has ended, daylight lasts almost $24 \mathrm{hr}$ and we believe muskoxen then actively seek ungrazed meadows in which to forage. This would coincide with the time (April and May) when muskox show an increase in energy expenditure (Lawler \& White 1997). Whether the pattern is the same in areas of low muskox density is unknown because of a lack of data.

The similarity between the diets of Peary caribou and muskoxen in high density areas during any given month was $<40 \%$ except during June, when there was substantial diet similarity $(71 \%$; Table 1). However, diet similarity in any given month does not completely address the potential for food competition. Foraging during the nongrowing season clearly has a direct impact on the availability of forage in the non-growing season, but it may also impact availability in the following growing season. The June diet of Peary caribou shows substantial similarity to the June, July, September, October and December diets of muskoxen-particularly in their willow componentsand the September and October diets of muskoxen have substantial overlap with the June, July and August diets of Peary caribou. Therefore for five months of the year the diet of muskoxen is similar to the summer diet of caribou. Given this similarity between their diets, even though the two species may not forage in the same areas at the same time, there is potential for competition should food become limiting.

Inter-annual variation in diet could potentially affect our results, particularly if there were directional changes in diet over time or if greater or lesser sampling intensity occurred during a year in which diet was different from that in most years. Changes in the quality and/or availability of forages would be important factors in interannual variation in diet. Larter \& Nagy (2001b) found annual variability in the quality of forages on Banks Island, but these changes were consistent across all forages and across areas of both high and low muskox density. There was annual variation in the standing crop of forages on Banks Island, but this was not consistent across habitat types (N. Larter \& J. Nagy unpubl. data). Given the variability in diet of individual caribou and groups of muskoxen, and the lack of evidence for any directional change in forage quality or availability, any inter-annual variability in diet would not drastically affect the dietary patterns we describe.

Although data were not collected specifically to investigate changes in diet that may be related to winter forage availability, many faecal samples were collected during a period when winter snow conditions (Larter \& Nagy 2000) and winter 
foraging behaviour (Larter \& Nagy 2001d) were investigated. Winters 1996-97 and 1997-98 were less severe with shallower and softer snow cover than previous winters; there was very little snow cover in November 1997 (Larter \& Nagy 2000; 2001d). Shallower snow conditions in early winter may have increased lichen availability, as suggested by the observation that the amount of lichen in the November diet of Peary caribou in 1997 was larger than November in other years, $10.3 \%$ $(n=5)$ in 1997 , versus mean of $1.4 \%(n=44)$ in 1991, 1993-96. Less severe snow conditions may also increase the availability of legumes relative to Dryas integrifolia for caribou. The absolute amount of legume and the ratio of D. integrifolia to legume in the November diet of caribou during 1996 and $1997(n=10)$ was greater than for four $(n=39)$ of the previous years (41 versus $27 \%$ and 1.1 versus 0.9 , respectively). Acquiring a higher proportion of legumes and consequently a diet of higher protein content during winter could be advantageous for Banks Island Peary caribou.

The numbers of both muskoxen and Peary caribou on Banks Island have remained high over the past decade: 50000 to 65000 muskoxen over the age of one year, and 500 to 1200 caribou over the same age (Nagy et al. 1996; Larter \& Nagy 1997; J. Nagy \& N. Larter unpubl. data). In addition to Peary caribou and muskoxen herbivory, Arctic willows make up a considerable amount of the winter diets of Arctic hares (Lepus arcticus) and ptarmigan (Lagopus mutus, L. lagopus) (Klein \& Bay 1990; Larter 1999; N. Larter \& D. Hik unpubl. data). Can willows sustain the substantial amounts of herbivory to which they are currently being exposed? Willows that were released from browsing on Banks Island did not alter the ratio of leaf biomass to stem diameter compared to browsed plants; however, plants that were not browsed had larger diameter stems resulting in an increase in total leaf biomass of $30 \%$ (Larter \& Hik in press). Arctic willows appear to be relatively tolerant of herbivory, but there is some indication that vegetative growth is becoming dominated by younger and narrower stems. Should herbivory on willows result in reduced willow biomass, the Peary caribou population would incur more of a negative impact than the muskoxen population because caribou feed selectively on high quality willows during summer when the animals are growing and putting on fat reserves. A reduction in willow biomass would reduce the potential for caribou numbers to increase.

Larter \& Nagy 2004: Polar Research 23(2), 131-140
Acknowledgements.-We thank the following for field and lab assistance during the course of the study: S. Baryluk, A. Esau, E. Esau, L. Gordon, S. Gray, J. Lennie, J. Lucas Sr., T. Lucas, F. Raddi, L. Raddi, P. Raddi, W. Raddi, and D. Semple. We thank all the hunters in Sachs Harbour who provided caribou faecal samples. T. Foppe and colleagues at the Composition Analysis Lab are gratefully acknowledged for comments and insight into the microhistological technique. S. Carrière provided comments on early drafts of this manuscript. Major funding for this project was provided through the Inuvialuit Final Agreement.

\section{References}

Barker, R. D. 1986: An investigation into the accuracy of herbivore diet analysis. Aust. Wildl. Res. 13, 559-568.

Chapin, F. S., III., Johnson, D. A. \& McKendrick, J. D. 1980: Seasonal movement of nutrients in plants of differing growth form in an Alaskan tundra ecosystem: implications for herbivory. J. Ecol. 68, 189-209.

Conover, W. J. 1980: Practical nonparametric statistics $2^{\text {nd }}$ edition. New York: John Wiley \& Sons, Inc.

Dauphine, Jr., T. C. 1976: Growth, reproduction and energy reserves. Part 4: Biology of the Kaminuriak population of barren-ground caribou. Can. Wildl. Serv. Rep. Ser. 38.

Ferguson, R. S. 1991: Detection and classification of muskox habitat on Banks Island, Northwest Territories, Canada, using Landsat thematic mapper data. Arctic 44, 66-74.

Hansen, R. M., Foppe, T . M., Gilbert, M. B., Clark, R. C. \& Reynolds, H. W. 1976: The microhistological analyses of feces as an estimator of herbivore diet. Unpublished report available from the Department of Range Science, Colorado State University, Ft. Collins, CO, USA

Hartley, S. E. \& Jones, C. G. 1997: Plant chemistry and herbivory: or why the world is green. In M. J. Crawley (ed) Plant Ecology. 2nd Edition. Pp. 284-324. Oxford: Blackwell Scientific.

Hofmann, R. R. 1989: Evolutionary steps of ecophysical adaption and diversification of ruminants: a comparative view of their digestive system. Oecologia 78, 443-457.

Hofmann, R. R. 2000: Functional and comparative digestive system anatomy of Arctic ungulates. Rangifer 20, 71-81.

Ihl, C. 1999: Comparative habitat and diet selection of muskoxen and reindeer on the Seward Peninsula, western Alaska. MSc thesis, University of Alaska, Fairbanks.

Ihl, C. \& Klein, D. R. 2001: Habitat and diet selection by muskoxen and reindeer in western Alaska. J. Wildl. Manage. 65, 964-972.

Johnson, M. K., Wofford, H. \& Pearson, H. A. 1983: Digestion and fragmentation: influence on herbivore diet analysis. J. Wildl. Manage. 47, 877-879.

Kartesz, J. T. 1999: A synonymized checklist and atlas with biological attributes of the vascular flora of the United States, Canada, and Greenland. First Edition. In J. T. Kartesz \& C. A. Meacham (eds): Synthesis of the North American flora, electronic version 1.0. Chapel Hill, North Carolina: North Carolina Botanical Garden.

Kevan, P. G. 1974: Peary caribou and muskoxen on Banks Island. Arctic 27, 256-264.

Klein, D. R. 1992: Comparative ecological and behavioral adaptions of Ovibos moschatus and Rangifer tarandus. Rangifer 12, 47-55. 
Klein, D. R. \& Bay, C. 1990: Foraging dynamics of muskoxen in Peary Land, northern Greenland. Holarctic Ecol. 13, 269-280.

Krebs, C. J. 1989: Ecological methodology. New York: Harper and Row Publishing.

Larter, N. C. 1999: Seasonal changes in arctic hare, Lepus arcticus, diet composition and differential digestibility. Can. Field Natural. 113, 481-486.

Larter, N. C. \& Hik, D. S. in press: Response of arctic willow (Salix arctica) following release from herbivory in a High Arctic ecosystem. Arctic.

Larter, N. C. \& Nagy, J. A. 1997: Peary caribou, muskoxen and Banks island forage: assessing seasonal diet similarities. Rangifer 17, 9-16.

Larter, N. C. \& Nagy, J. A. 2000: Annual and seasonal differences in snow depth, density, and resistance in four habitats on southern Banks Island, 1993-1998. Department of Resources, Wildlife \& Economic Development, Manuscript Report 136.

Larter, N. C. \& Nagy, J. A. 2001a: Calf production, calf survival, and recruitment of muskoxen on Banks Island during a period of changing population density from 1986-1999. Arctic 54, 394-406.

Larter, N. C. \& Nagy, J. A. 2001b: Seasonal and annual variability in the quality of important forage plants on Banks Island, Canadian High Arctic. Appl. Veg. Sci. 4, 115-128.

Larter, N. C. \& Nagy, J. A. 2001c: Variation between snow conditions at Peary caribou and muskox feeding sites and elsewhere in foraging habitats on Banks Island in the Canadian High Arctic. Arct. Antarct. Alp. Res. 33, 123-130.

Larter, N. C. \& Nagy, J. A. 2001d: Distribution of forage types among four terrestrial habitats on southern Banks Island. Department of Resources, Wildlife \& Economic Development, Manuscript Report 142.

Lawler, J. P. \& White, R. G. 1997: Seasonal changes in metabolic rates of in muskoxen following twenty-four hours of starvation. Rangifer 17, 135-138.

Leader-Williams, N. 1980: Population ecology of reindeer on south Georgia. In E. Reimers, E. Gaare \& S. Skjenneberg (eds): Proceedings of the Second International Reindeer/ Caribou Symposium, Røros, Norway, 1979. Pp. 664-676. Trondheim: Direktoratet for vilt og ferskvannsfisk.

McKendrick, J. D. 1981: Responses of arctic tundra to intensive muskox grazing. Agroborealis 12, 49-55.

Mulder, C. P. H. \& Harmsen, R. 1995: The effect of muskox herbivory on growth and reproduction in an arctic legume. Arct. Alp. Res. 27, 44-53.

Murray, J. L. 1991: Biomass allocation and nutrient pool in major muskoxen-grazed communities in Sverdrup Pass, $79^{\circ}$ N, Ellesmere Island, N.W.T., Canada. MSc thesis, University of Toronto.

Nagy, J. A., Larter, N. C. \& Fraser, V. P. 1996: Population demography of Peary caribou and muskox on Banks Island, N.W.T., 1982-1992. Rangifer 9, 213-222.

Oakes, E. J., Harmsen, R. \& Eberl, C. 1992: Sex, age, and seasonal differences in the diets and activity budgets of muskoxen (Ovibos moschatus). Can. J. Zool. 70, 605-616.

Parker, G. R. 1978: The diets of muskoxen and Peary caribou on some islands in the Canadian High Arctic. Canadian Wildlife Service, Occasional Paper 35.

Porsild, A. E. \& Cody, W. J. 1980: The vascular plants of continental Northwest Territories, Canada. Ottawa: National Museum of Canada.

Raillard, M. 1992: Influence of muskox grazing on plant communities of Sverdrup Pass $\left(79^{\circ} \mathrm{N}\right)$, Ellesmere Island; $N \mathrm{WT}$, Canada. PhD thesis, University of Toronto.
Reimers, E., Villmo, L., Gaare, E., Holthe V. \& Skogland, T. 1980: Status of Rangifer in Norway including Svalbard. In E. Reimers, E. Gaare \& S. Skjenneberg (eds): Proceedings of the Second International Reindeer/Caribou Symposium, Røros, Norway, 1979. Pp. 774-785. Trondheim: Direktoratet for vilt og ferskvannsfisk.

Renkonen, O. 1938: Statistisch-ökologische Untersuchungen über die terrestriche Käferwelt der finnischen Bruchmoore. (Statistical-ecological investigation of the terrestrial beetle population of Finnish bogs.) Ann. Zool. Soc. Bot. Fenn. Vanamo 6, 1-231.

Schaefer, J. A. \& Messier, F. 1995a: Habitat selection as a hierarchy: the spatial scales of winter foraging by muskoxen. Ecography, 18: 333-344.

Schaefer, J. A. \& Messier, F. 1995b: Winter foraging by muskoxen: a hierarchical approach to patch residence time and cratering behaviour. Oecologia, 104: 39-44.

Shank, C. C., Wilkinson, P. F. \& Penner, D. F. 1978: Diet of Peary caribou, Banks Island, N.W.T. Arctic 31, 125-132.

Sparkes, D. R. \& Malechek, J. C. 1968: Estimating percentage dry weights using a microscopic technique. J. Range Manage. 21, 264-265.

Svendsen, C. R. 1992: Utilizaion of riparian willow stands during summer by moose, muskoxen, and reindeer on the Seward Peninsula, Alaska. In B. Bobek, K. Perzanowski \& W. Regelin (eds): Global trends in wildlife management. Transactions of the 18th International Union of Game Biologists Congress, Krakow, Poland, 1987. Pp. 233-236. Krakow-Warszawa: Swiat Press.

Thing, H. 1984: Feeding ecology of the West Greenland caribou (Rangifer tarandus groenlandicus) in the SisimiutKangerlussuaq Region. Dan. Rev. Game Biol. 12, 1-53.

Thing, H., Klein, D. R., Jingfors, K. \& Holt, S. 1987: Ecology of muskoxen in Jameson Land, northeast Greenland. Holarctic Ecol. 10, 95-103.

Thomas, D. C. 1982: The relationship between fertility and fat reserves of Peary caribou. Can. J. Zool. 60, 597-602.

Thomas, D. C. \& Edmonds, J. E. 1983: Rumen contents and habitat selection of Peary caribou in winter, Canadian arctic archipelago. Arct. Alp. Res. 15, 97-105.

Thomas, D. C. \& Edmonds, J. E. 1984: Competition between caribou and muskoxen, Melville Island, NWT, Canada. Biological Papers of the University of Alaska, Special Report 4, 93-100.

Thomas, D. C., Edmonds, E. J. \& Armbruster, H. J. 1999: Range types and their relative use by Peary caribou and muskoxen on Melville Island, N. W. T. Canadian Wildlife Service, Technical Report Series Number 343.

Tyler, N. J. C. \& Blix, A. S. 1990: Survival strategies in arctic ungulates. Rangifer Special Issue 3, 211-230.

Urquhart, D. R. 1973: Oil exploration and Banks Island wildlife. A guideline for the preservation of caribou, muskox and arctic fox populations on Banks Island, N.W.T. Northwest Territories Game Management Division. Unpublished manuscript available at the Department of Resources, Wildlife and Economic Development, Government of the Northwest Territories, Yellowknife, NT, Canada X1A 2L9.

White, R. G. 1983: Foraging patterns and their multiplier effects on productivity of northern ungulates. Oikos 40,377-384.

Wilkinson, P. F., Shank, C. C. \& Penner, D. F. 1976: Muskoxcaribou summer range relations on Banks Island, N. W. T. J. Wildl. Manage. 40, 151-162.

Zoltai, S. C., Karasiuk, D. J. \& Scotter, G. W. 1980: A natural resource survey of the Thomsen River area, Banks Island, N. W. T. Unpublished report prepared for Parks Canada, available at Canadian Wildlife Service, Edmonton, Alberta, Canada, T6V $2 \mathrm{X} 3$. 